\title{
Prospect and Challenges in Broiler Farming of Barguna District in Bangladesh
}

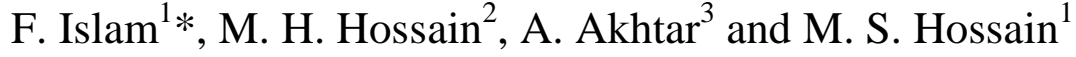 \\ Dept. of Animal Breeding and Genetics, Bangladesh Agricultural University, Mymensingh ${ }^{1}$ \\ Deputy Manager - Livelihoods, Nobo Jibon, Save the Children, Project Office, Barguna ${ }^{2}$ \\ Department of Livestock Services, Dhaka, Bangladesh ${ }^{3}$
}

Corresponding author : farukkrishibid@gmail.com

\begin{abstract}
A total of 21 farms and 10542 broiler birds from 12 villages of 3 upazila under Barguna district in Bangladesh during June 2014 to July 2014 were studied. Among selected farms, 47.62\% were small (200-450 birds) and 52.38\% were medium (500-1000 birds) and most of the farmers (71.40\%) were with secondary level education while majority (61.90\%) had no training in broiler farming. However, 42.86\% farmers reared Hubbard Classic and 38.09\% reared Cobb-500 while the rest farmers reared Arber Aceres, Ross and Lohmanh commercial hybrid broiler. Several poultry hatcheries and feed companies were involved to supply day old chicks and feeds through their respective dealers to the broiler farmers in the study area. All broiler houses were open sided and most of them (85.71\%) were with gable type roof of corrugated iron sheet. Most of the farmers (95.20\%) were using sawdust as litter materials and all farmers were using the disposed litter as fertilizer. All farmers were using electric brooder and brooding their birds for 7 days while $85.70 \%$ farmers were using hurricane lantern for standby power supply for brooding period. All farmers were using Newcastle and Infectious Bursal Disease vaccine and $81 \%$ farmers were deworming their birds. About $85.7 \%$ farmers reported that Marek's disease vaccine were administered in day old chicks at hatchery level while $81 \%$ farmers sale their live broiler at local market and about 52.40\% farmers use their disposed feed bags of their own farm and household purpose. Mean live broiler weight at marketing age, feed conversion ratio and bird mortality rate were $1502.38 \pm 35.27 \mathrm{gm}, 1.93 \pm 0.04$ and $3.51 \pm 0.65 \%$, respectively. Maximum broiler farmers had secondary level education and had no training. Broiler farming in Barguna district has generated employment opportunity in this sector. Bank loan with easy access and lower rate of interest might be helpful for the broiler farmers to run their enterprise without dependency on dealers. Field survey primary data and farmers opinion regarding day old chicks price and live broiler marketing suggested that selling live broiler at high price and buying day old chick at low price make the farm operation profitable and vice versa. Again farmer's opinion suggested that higher feed price is reducing the profitability of broiler farms. Hence, it might be concluded that higher feed price and day old chicks and live broiler market instability are the major challenges in broiler farming in Barguna district of Bangladesh.
\end{abstract}

Key words: Prospect, challenges, broiler farming, feed, chicks and market instability

\section{Introduction}

Bangladesh is one of the high density countries of the world has a population of 160 million people within the area of $1,47,570$ square-km, both government and non-government organizations are actively promoting poultry development at all levels here. During last two decades this sector has grown with an annual rate of around 20 per cent. Poultry sector has enabled the opportunity to change 
livelihood and food habit, reduced the dependence of beef and mutton as animal protein sources as well as helping to ensure food security (Islam et al., 2014). This industry as a fundamental part of animal production is committed to supply the nation a cheap source of good quality nutritious animal protein in terms of meat and egg (Akter and Uddin, 2009) and creating purchasing power and reducing poverty at a large scale, about 44 per cent of daily human intake of animal protein comes from livestock products (Islam et al., 2014). Investment in the sector stands at about Taka 200 billion. There are over a 100 thousand poultry farms, small and large, across the country, eight grand-parent (GP) stock farms, 130 parent stock farms and hatcheries, and 50 or 60 poultry feed mills. About five million people are involved, directly and indirectly, with the industry. A large section of the marginalized rural people earns their living through this industry. One-third of total agricultural contribution (18.60\%) in GDP added from poultry industry (Khaled, 2014). Profitability of broiler production involves planning the activity size, demand assessment, integration of activities to bring down the cost of production, possible foresight into market price situations, prudent assessment of cost-benefits and finally the rate of returns in the activity (Sultana et al., 2012). Factors associated with broiler farming could vary from region to region. Published data with systematic study regarding broiler farming in Barguna district is scanty. So to explore the present prospect and challenges of commercial broiler farming in Barguna district this study was under taken.

\section{Materials and Method}

The study was conducted to investigate the prospects and challenges of broiler farming in Barguna district. To pursue the study a pre prescribed questionnaire was used and 5 broiler farms from Amtoli upazila, 10 broiler farms from Barguna sadar upazila and 6 broiler farms from Patharghata upazila of Barguna district in Bangladesh were enumerated by door to door visit. Farmers characters like education level, training, experiences and work forces on broiler farming were recorded while farm management parameters like farm size, housing system, commercial hybrid broiler strains, litter materials, drinks during loading day old chicks in house, brooding system, vaccination, de-worming, growth promoter use, day old chicks purchase, feed purchase and live broiler marketing were studied. Data were collected on day old chick weight, live broiler weight at market age, feed consumption, number of birds sold and mortality during June 2014 to July 2014. Feed conversion ratio (FCR), mortality rate up to age of marketing (MTRT), feed cost in Bangladeshi Taka (BDT) per kg live broiler production $(\mathrm{FCP})$, vaccination and growth promoter expenses per kg live broiler production (VGCP) were calculated using following formulae:

Total feed $(\mathrm{kg})$ consumed up to the age of marketing

$\mathrm{FCR}=\frac{\text { Total live weight }(\mathrm{kg}) \text { of bird at marketing day }}{\text { Tot }}$

Total birds dead up to the age of marketing

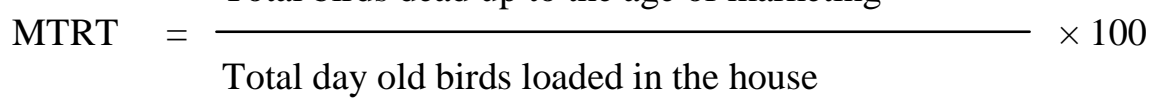

Total feed consumed in $\mathrm{kg} \times$ feed price in BDT per $\mathrm{kg}$

$\mathrm{FCP}=\frac{\text { Total live broiler production in } \mathrm{kg}}{}$

Total vaccines and growth promoter expenses in BDT

$\mathrm{VGCP}=\frac{\text { Total live broiler production in } \mathrm{kg}}{}$ 
Farm management and production performance data were analyzed using frequency and descriptive statistics menu in SPSS 11.5 software package.

\section{Results and Discussion}

\section{Farmers and farm background}

Educational background of the farmers, as observed in the present study (Table 1), 19\% were within the primary level, $71.40 \%$ were secondary and remaining $9.50 \%$ were within the graduate level, suggesting that the maximum farmers handling broiler farms were within the secondary level of education. The results were consistent with the previous report of Sultana et al. (2012) and Rahman et al. (2002). About $38.10 \%$ farmers received short training on broiler farming whereas about $61.90 \%$ did not take any training at all and this might be indicative that majority of broiler farms are operating by untaught manpower. The result is contradictory with Sultana et al. (2012) and Rahman et al. (2003), who reported that $70 \%$ had training on broiler farming. Among the broiler farmers $66.70 \%$ had experience for below 3 years while the rest had experience for 3 years and above. This might be suggested that most of the broiler farmers were novice and less experienced. More interestingly it was reported that $81 \%$ farmers themselves were working in their farm while the family members of other farmer were also working with them in their broiler farm. This is indicating that broiler farming in Barguna district generating employment at farmers and family level.

Table 1. Farmer's characters and farm size

\begin{tabular}{|c|c|c|c|c|}
\hline \multicolumn{2}{|l|}{ Parameter } & $\begin{array}{l}\text { Numb } \\
\text { er }\end{array}$ & $\%$ & Total \\
\hline \multirow{3}{*}{ Education } & Primary Level & 4 & 19.00 & \multirow{3}{*}{100} \\
\hline & Secondary Level & 15 & 71.40 & \\
\hline & Graduate Level & 2 & 9.50 & \\
\hline \multirow[t]{2}{*}{ Training on broiler rearing } & Yes & 8 & 38.10 & \multirow[t]{2}{*}{100} \\
\hline & No & 13 & 61.90 & \\
\hline \multirow[t]{2}{*}{ Experiences } & Below 3years & 14 & 66.70 & \multirow[t]{2}{*}{100} \\
\hline & 3 years and above & 7 & 33.30 & \\
\hline \multirow[t]{2}{*}{ Work forces } & Owner of the farm & 17 & 81.00 & \multirow[t]{2}{*}{100} \\
\hline & Owner and family member & 4 & 19.00 & \\
\hline \multirow[t]{2}{*}{ Farm size } & Small farm (200 to 450birds) & 10 & 47.62 & \multirow[t]{2}{*}{100} \\
\hline & $\begin{array}{l}\text { Medium farm (500 to } \\
\text { 1000birds) }\end{array}$ & 11 & 52.38 & \\
\hline \multirow{5}{*}{$\begin{array}{l}\text { Commercial hybrid broiler } \\
\text { strains }\end{array}$} & Cobb-500 & 8 & 38.09 & \multirow[t]{5}{*}{100} \\
\hline & Hubbard Classic & 9 & 42.86 & \\
\hline & Arber Acere & 2 & 9.52 & \\
\hline & Ross & 1 & 4.76 & \\
\hline & Lohmanh & 1 & 4.76 & \\
\hline
\end{tabular}

Present study revealed that about $47.62 \%$ were small farms (200-450 birds) and 52.38\% medium (5001000 birds) and the result was in line with Sultana et al. (2012). About $42.86 \%$ farmers reared Hubbard Classic, 38.09\% reared Cobb-500 while the rest farmers reared Arber Aceres, Ross and Lohmanh commercial hybrid birds and the present result was contradictory to the previous report of Hauque (2005), Sharma (2003) and Sultana et al. (2012). These researchers reported that most of the farmers were rearing Cobb-500 commercial hybrid broiler birds. 


\section{Feeds and chicks supply}

Several poultry hatcheries and feed companies were involved to supply raw materials like day old chicks and feeds through their respective dealers to the broiler farmers in the study area (Table 2) and this is suggesting that farmers have opportunity to collect feed and chick with competitive price but as the farmers are collecting chicks and feed from dealer, dealers might be taking opportunity instead farmers. However, Sultana et al. (2012) reported that most of the farmers were rearing the chicks of Kazi Farms Limited in Santhia upazila under Pabna district.

Table 2. Lists of Hatcheries and Feed companies involved

\begin{tabular}{|l|l|}
\hline Name of Poultry Hatcheries & Name of Poultry Feed Company \\
\hline Aftab Hatchery Ltd. & ACI Godrej Agrovet Private Ltd. \\
\hline Aman Poultry and Hatchery Ltd. & Aftab Feed. Products Ltd. \\
\hline Bangladesh Hatchery Ltd. & Aman Feed Ltd. \\
\hline C.P. Bangladesh Ltd. & Index Agro Industries Ltd. \\
\hline Index Poultry (PVT) Ltd. & Lion Feeds Ltd \\
\hline Kazi Hatchery Ltd. & Nourish Feeds Ltd. \\
\hline Nourish Poultry and Hatchery Ltd. & \\
\hline Paragon Poultry Ltd. & \\
\hline
\end{tabular}

\section{Factors related to broiler farming}

All broiler houses were open sided and about $85.71 \%$ were with gable type roof of corrugated iron sheet (CIS) and the rest were shed type roof with CIS (Table 3). Most of the farmers $(95.20 \%)$ were using sawdust as litter materials while all farmers were using the disposed litter as fertilizer, all farmers were using electric brooder and brood their birds for 7 days while $85.70 \%$ farmers were using hurricane lantern and the rest were using solar power for standby power supply for brooding period. During loading the birds in the house most of the farmers use oral saline, vitamin $\mathrm{C}$ with water. Most of the farmers purchase feed from the dealer in credit and partial credit and about $66.70 \%$ farmers do not weigh the feed after purchase. Procuring feed in credit from dealer might be indicating the financial weakness of farmers and this might be making them dependable on dealer. All farmers were using Newcastle and Infectious Bursal Disease vaccine for the commercial hybrid broiler birds, $81 \%$ farmers were de-worming and the rest were not doing this job, $100 \%$ farmers were using growth promoter for rapid gain of body weight of broiler birds. However, Sultana et al. (2012) reported 90\% farmers and Rahman (2004) 70\% farmers were using vaccines regularly. Present study revealed, about $85.7 \%$ farmers reported that Marek's disease vaccine were administered in day old chicks at hatchery level while the rest reported that this vaccine was not given. About $81 \%$ farmers sale their live broiler at local market and about $52.40 \%$ farmers use their disposed feed bags in their own farm and household purpose.

\section{Broiler production performances}

Field survey primary data reported live weight of broiler $1502.38 \pm 35.27 \mathrm{gm}$ at marketing age, feed conversion ratio $1.93 \pm 0.04$ and mortality rate $3.51 \pm 0.65 \%$ (Table 4). Similarly, Hauque (2005) found $1.5 \mathrm{~kg}$ average market weight per bird but Sultana et al. (2012) reported live broiler market weight 1.5 to $1.8 \mathrm{~kg}$ and Perry et al. (1999) also found market weight $1.07 \mathrm{~kg}$ to $1.70 \mathrm{~kg}$ per bird. However, the feed conversion ratio of present study was similar to Chand et al. (2009), who reported the values to be 1.93 to 1.94 but Kawsar et al. (2013) reported that training and management intervention could contribute to lower the FCR value (1.49 to 1.53) and higher the productivity in hybrid broiler farming. This discussion might be suggested that training of farmers could contribute to reduce feed cost by reducing the FCR value. 
Table 3. Factors related to broiler farming

\begin{tabular}{|c|c|c|c|c|}
\hline \multicolumn{2}{|l|}{ Parameter } & Number & $\%$ & Total \\
\hline \multirow{5}{*}{ Drinks during shed } & Oral saline mixed water & 5 & 23.80 & \multirow[t]{5}{*}{100} \\
\hline & Vitamin C mixed water & 4 & 19.00 & \\
\hline & Glucose mixed water & 1 & 4.80 & \\
\hline & $\begin{array}{l}\text { Oral saline and Vitamin } \mathrm{C} \text { mixed } \\
\text { water }\end{array}$ & 6 & 28.60 & \\
\hline & $\begin{array}{l}\text { Oral saline, vitamin } \mathrm{C} \text { and lemon } \\
\text { juice mixed water }\end{array}$ & 5 & 23.80 & \\
\hline \multirow{2}{*}{$\begin{array}{l}\text { Roof type of open } \\
\text { sided broiler house }\end{array}$} & Shed type roof with C.I. Sheet & 3 & 14.29 & \multirow{2}{*}{100} \\
\hline & Gable type roof with C.I. Sheet & 18 & 85.71 & \\
\hline Brooding type & Electric & 21 & 100 & 100 \\
\hline \multirow[t]{2}{*}{ Standby power } & Lantern hurricane & 18 & 85.70 & \multirow[t]{2}{*}{100} \\
\hline & Solar power & 3 & 14.30 & \\
\hline \multirow{2}{*}{ Litter materials used } & Rice husk & 1 & 4.80 & \multirow[t]{2}{*}{100} \\
\hline & Sawdust & 20 & 95.20 & \\
\hline Vaccine used & $\begin{array}{l}\text { Newcastle and Infectious Bursal } \\
\text { Disease vaccine }\end{array}$ & 21 & 100 & 100 \\
\hline \multirow[t]{2}{*}{ De-worming } & Yes & 17 & 81.00 & \multirow[t]{2}{*}{100} \\
\hline & No & 4 & 19.00 & \\
\hline $\begin{array}{l}\text { Uses of growth } \\
\text { promoter }\end{array}$ & Yes & 21 & 100 & 100 \\
\hline \multirow[t]{4}{*}{ Feed purchase type } & Cash purchase & 3 & 14.30 & \multirow[t]{4}{*}{100} \\
\hline & Credit Purchase & 3 & 14.30 & \\
\hline & Partial cash purchase & 8 & 38.10 & \\
\hline & Cash and Credit purchase & 7 & 33.30 & \\
\hline \multirow{2}{*}{$\begin{array}{l}\text { Weighing feed after } \\
\text { purchase }\end{array}$} & Yes & 7 & 33.30 & \multirow[t]{2}{*}{100} \\
\hline & No & 14 & 66.70 & \\
\hline \multirow[t]{2}{*}{ Broiler sales place } & Market & 17 & 81.00 & \multirow[t]{2}{*}{100} \\
\hline & Farm gate & 4 & 19.00 & \\
\hline \multirow{2}{*}{$\begin{array}{l}\text { Usage of disposed } \\
\text { feed bag }\end{array}$} & Sold & 10 & 47.60 & \multirow[t]{2}{*}{100} \\
\hline & Own use & 11 & 52.40 & \\
\hline $\begin{array}{l}\text { Usage of disposed } \\
\text { litter }\end{array}$ & Fertilizer & 21 & 100 & 100 \\
\hline \multirow[t]{2}{*}{ Marek's vaccine } & Yes & 18 & 85.70 & \multirow[t]{2}{*}{100} \\
\hline & No & 3 & 14.30 & \\
\hline Brooding period & 7days & 21 & 100 & 100 \\
\hline
\end{tabular}

Table 4. Broiler production performance

\begin{tabular}{|l|l|l|l|}
\hline Parameter & Mean \pm SE & Max & Min \\
\hline Live weight of broiler at Marketing age in gm & $1502.38 \pm 35.27$ & 1800 & 1200 \\
\hline Mortality Rate in \% & $3.51 \pm 0.65$ & 10 & 0 \\
\hline Feed Conversion Ratio & $1.93 \pm 0.04$ & 2.42 & 1.65 \\
\hline
\end{tabular}

\section{Benefit cost information in broiler farming}

A total of 10970 day old broiler birds with 20 to $75 \mathrm{gm}$ body weight were loaded in the farms and a total of 10542 birds were sold with 1200 to $1800 \mathrm{gm}$ body weight at marketing. Broiler birds were 
marketing at the age of 30 to 35 days. Feed price per kg was 45.89 BDT (Table 5). Day old chick's price varied in a wide range of 27 to $60 \mathrm{BDT}$. Average feed cost per kg live broiler production was 89.23 BDT while vaccine and growth promoter purpose expenses for per kg live broiler production was documented 3.70 BDT. However, live broiler market price was reported 120 to 160 BDT per kg. It might be indicative that day old chicks and live broiler market were highly fluctuating and this might be suggested that selling live broiler at high price and buying day old chick at low price make the farm operation profitable and vice versa. On the other hand Sultana et al. (2012) reported per kg live broiler production cost 90 to 104 BDT while live broiler price per kg body weight was 110 to 125 BDT and Karim (2001) reported wide range of fluctuation of live broiler market price.

Table 5. Benefit cost information of broiler farming in rural villages of Barguna district

\begin{tabular}{|l|l|}
\hline Parameter & amount \\
\hline Total number of day old chicks loaded in the house & 10970 \\
\hline Day old chick weight in gm & $20-75$ \\
\hline Live broiler weight in gm & $1200-1800$ \\
\hline Marketing age of broiler in days & $30-35$ \\
\hline Day old chick Price in BDT & $27-60$ \\
\hline Total number of broiler bird sold & 10542 \\
\hline Total live broiler sold (kg) & 15660.25 \\
\hline Total feed consumed (kg) & 30449 \\
\hline Feed price per kg in BDT & 45.89 \\
\hline Total expenses on feed purpose in BDT & 1397304.61 \\
\hline Total expenses on vaccine and growth promoter purpose in BDT & 57890.00 \\
\hline Feed cost per kg live broiler production in BDT & 89.23 \\
\hline $\begin{array}{l}\text { Vaccination and growth promoter purpose expenses per kg live broiler } \\
\text { production in BDT }\end{array}$ & 3.70 \\
\hline Per kg live broiler sold (BDT) & $120-160$ \\
\hline
\end{tabular}

\section{Challenges in broiler farming}

About $66.70 \%$ farmers reported that they were getting the day old chicks lately while $33.30 \%$ were getting timely (Table 6). However all farmers were reported that live broiler market was highly unstable and day old chicks, feeds and growth promoter price were high and these minimized the profitability in broiler farming. Similarly Sultana et al. (2012) reported high price of feed and price variation of day old chick in Santhia upazila under Pabna district. This discussion might be indicative that feed and chicks price and live broiler market instability were the major challenges in broiler farming in Barguna district.

Table 6. Farmer's opinion

\begin{tabular}{|l|l|l|l|l|}
\hline Challenges identified by farmers in broiler farming & Number & $\%$ & Total \\
\hline Transportation delayed during chick collection & Yes & 14 & 66.70 & 100 \\
\cline { 2 - 4 } & No & 7 & 33.30 & \\
\hline Live broiler market fluctuated & Yes & 21 & 100 & \multirow{2}{*}{100} \\
\cline { 2 - 4 } & No & 0 & 0 & \\
\hline \multirow{2}{*}{$\begin{array}{l}\text { Cost of day old chicks, feed and growth promoter were } \\
\text { high and these minimized the profitability }\end{array}$} & Yes & 21 & 100 & \multirow{2}{*}{100} \\
\cline { 2 - 4 } & No & 0 & 0 & \\
\hline
\end{tabular}




\section{Conclusion}

Broiler farming has bright prospects in generating employment in Barguna district of the manpower with secondary level education and without training and having less experience. As several poultry hatcheries and feed companies are supplying chicks and feeds, farmers have opportunity to collect feed and chick with competitive market price but as the farmers are collecting chicks and feed from dealer, dealers might be taking opportunity instead farmers. Procuring feed in credit from dealer might be indicating the financial weakness of farmers and this might be making them dependable on dealer. Bank loan with lower rate of interest might be helpful for the broiler farmers to run their enterprise without dependency on dealers. Day old chicks price and live broiler marketing suggested that selling live broiler at high price and buying day old chick at low price make the farm operation profitable. The study revealed that higher feed price and day old chicks and live broiler market instability were the major challenges in broiler farming in Barguna district of Bangladesh.

\section{Acknowledgements}

Authors are thankful to the broiler farmers of South Amtoli, North Tarikata and Ghopkhali villages of Amtoli upazila, Burirkhal, Gilatoli and South Badurtola villages of Barguna sadar upazila and East Kalomegha, South Kalomegha, South Hoglapasha, East Lemua, Kironpur and Middle Manikkhali villages of Patharghata upazila under the district of Barguna in Bangladesh.

\section{References}

Akter, S. and Uddin, M. (2009). Bangladesh poultry industry. Journal of Business and Technology 4: 97-112.

Chand, V., Chowdhury, S. D., Saha, M. and Hossain, M. K. (2009). IFC-SEDF Sector Studies and Baseline Surveys in Poultry in Bangladesh, Final Report. Associates for Development Services Limited, Dhaka.

Hauque, S. (2005). Status of broiler farming in Sherpur sadar upazila. MS Thesis, Bangladesh Agricultural University, Mymensingh, Bangladesh.

Islam, M. K., Uddin, M.F. and Alam, M. H. (2014). Challenges and Prospects of Poultry Industry in Bangladesh. European Journal of Business and Management 6 (7): 116-127.

Kawsar, M. H., Chowdhury, S. D., Raha, S. K. and Hossain, M. M. (2013). Impact of management intervention on productive performance and profitability of small-scale broiler farming in Bangladesh. Livestock Research for Rural Development, volume 25.

Karim, M. R. (2001). Profitable analysis of broiler farming under contract farming system. MS Thesis, Bangladesh Agricultural University, Mymensingh. pp. 35-75.

Khaled, S. M. S. (2014). Poultry industry: Realities and prospects. The Financial Express, International Publication Limited. http://www.thefinancialexpress-bd.com, visited on 26 April 2014.

Perry, J., Banker, D. and Green, R. (1999). Broiler farms organization, management and performance. Agricultural Information Bulletin, United States Department of Agriculture, No. 748.

Rahman, M. M., Islam, M. R., Ullah, M. N. and Adeyl, F. M. M. (2002). Study on the scientific knowledge and management skill in commercial broiler farming program at the farmer level of Rajshahi district. Online Journal of Biological Science 2: 767-768.

Rahman, M., Roy, S. K. and Dey. M. S. (2003). Production performance of two broiler strains as affected by season and rural environment of Bangladesh. Pakistan Journal of Biological Science 6: 735-737. 
Rahman, W. M. (2004). Livestock and poultry rising as a poverty alleviation strategy in some selected area of Mymensingh. MS Thesis, Bangladesh Agricultural University, Mymensingh. pp. 4576.

Sharma, R. R. (2003). A study on the constraints encountered by broiler farmers in Haryana. Indian Journal of Poultry Science 38: 302-304.

Sultana, F., Khatun, H and Islam, A. (2012). Small scale broiler farming at Santhia upazilla of Pabna District of Bangladesh. Bangladesh Journal of Animal Science 41 (2): 116-119.

\section{Citation for this article (APA Style)}

Islam, F., Hossain, M. H., Akhtar, A. \& Hossain, M. S. (2014). Prospect and Challenges in Broiler Farming of Barguna District in Bangladesh. Journal of Bioscience and Agriculture Research, 02(01), 44-51. Retrieved November 04, 2014, from http://www.journalbinet.com/current-issue-jbar-1.html. 